\title{
Crab diversity and crab potential as support ecotourism in Teleng Ria, Grindulu and Siwil Beach, Pacitan, East Java, Indonesia
}

\author{
ROMZI MAULANA IRWANSYAH ${ }^{\mathbf{1}}$, SAVITRI INTAN NUR AZZAHRA ${ }^{\mathbf{1}}$, SALMA ARDELIA DARMASTUTI ${ }^{\mathbf{1}}$, \\ ANANDA RILO RAMADHANDI ${ }^{1}$, OLIVIA FIRDAUS ${ }^{1}$, FITRI DAENI $^{2}$, NADIRA SAFITRI ${ }^{2}$, \\ OCTA PRAMESWARI AMBANG FAJRI ${ }^{2}$, GILANG DWI NUGROHO ${ }^{3,4}$, DARLINA MD. NAIM ${ }^{5}$, \\ AHMAD DWI SETYAWAN ${ }^{1,6, \bullet}$ \\ ${ }^{1}$ Department of Environmental Science, Faculty of Mathematics and Natural Sciences, Universitas Sebelas Maret. Jl. Jend. Urip Sumoharjo No. 179, \\ Surakarta 57128, Central Java, Indonesia. Tel./fax.: +62-271-663375, ^email: volatileoils@ gmail.com \\ ${ }^{2}$ Department of Environmental Science, Faculty of Mathematics and Natural Sciences, Universitas Negeri Semarang. J1. Raya Sekaran, Gedung D5 \\ Lantai 1, Kampus FMIPA Unnes, Gunung Pati, Semarang 50229, Central Java, Indonesia \\ ${ }^{3}$ Department of Biology, Faculty of Mathematics and Natural Sciences, Universitas Sebelas Maret. Jl. Ir. Sutami 36A, Surakarta 57126, Central Java, \\ Indonesia \\ ${ }^{4}$ Biodiversity Study Club, Faculty of Mathematics and Natural Sciences, Universitas Sebelas Maret. Jl. Ir. Sutami 36A, Surakarta 57126, Central Java, \\ Indonesia \\ ${ }^{5}$ School of Biological Sciences, Universiti Sains Malaysia. 1112, Persiaran Sains, 11800 Gelugor, Pulau Pinang, Malaysia \\ ${ }^{6}$ Biodiversity Research Group, Universitas Sebelas Maret. J1. Ir. Sutami 36A, Surakarta 57126, Central Java, Indonesia
}

Manuscript received: 6 December 2021. Revision accepted: 29 December 2021.

\begin{abstract}
Irwansyah RM, Azzahra SIN, Darmastuti SA, Ramadhandi AR, Firdaus O, Daeni F, Safitri N, Fajri OPA, Nugroho GN, Naim DM, Setyawan AD. 2021. Crab diversity and crab potential as support ecotourism in Teleng Ria, Grindulu and Siwil Beach, Pacitan, East Java, Indonesia. Intl J Bonorowo Wetlands 11: 75-83. The mangrove area in Pacitan District, Pacitan, East Java, Indonesia, is generally not polluted. Therefore, the land is suitable for growing conditions from mangrove plants and has great potential as a mangrove area with ecotourism management in Indonesia. Ecotourism activities in mangrove areas, in principle, are the use of mangrove areas while maintaining the biological/ecological functions of mangrove areas that have social and economic value for the local community. The mangrove ecosystem is a habitat of various species of Crustacea, such as the crab. Crabs are live in coastal/mangrove ecosystems and one of the key species that have a very important role in maintaining the balance of the ecosystem. The study about the diversity of crabs in the mangrove area is very important because it will improve mangrove quality and potentially support ecotourism in the mangrove ecosystem. This study aims to determine the diversity of the crab and its potential to support ecotourism if the Pacitan Beaches are ecotourism in the future. This research was conducted in Teleng Ria Beach, Grindulu Beach, and Siwil Beach, Pacitan, East Java, Indonesia, in November 2021. Plots of $10 \times 10 \mathrm{~m} 2$ are made to record the species and the number of individual crab species. The result found five species of crab, i.e., Austruca annulipes (H. Milne-Edwards, 1837), Coenobita perlatus (H. Milne-Edwards, 1837), Ocypode kuhlii (De Haan, 1835), Perisesarma guttatum (A. Milne-Edwards, 1869), and Scylla serrata (Forsskål, 1775). The total crab diversity index of 1.25 is included in the medium category. The morphology, activity, number of individuals, and distribution of each crab species in an ecotourism area will increase the attractiveness of tourists to visit. For example, the morphology of $C$. perlatus that has the red color as a strawberry sometimes has a home/the shells of the Mollusca which color and unique shape so that add appeal to be seen. Then, the crab A. annulipes that like to dance and play the violin with the claw can also be attractions drawing tourists. Hopefully, the data can be a reference for the managers of the mangrove area in developing ecotourism and conservation of mangrove forest.
\end{abstract}

Keywords: Crab, diversity, ecotourism, mangrove, Pacitan

\section{INTRODUCTION}

Mangrove area can be defined as a forest type that grows in tidal areas, especially on protected beaches, lagoons, river mouths that are flooded and free from inundation at low tide whose plant communities tolerate salt (Kainuma et al. 2013; Junk et al. al. 2014). The benefits of mangroves in coastal areas are in the form of environmental distribution and neutralizing the presence of harmful pollutants, reducing approximately $50 \%$ of the strength of tsunami waves, and protecting coastlines. In addition, mangroves have a high productivity role compared to other ecosystems, thus making mangrove ecosystems necessary for the life of living things ( $\mathrm{Li}$ et al.,
2015). Furthermore, the mangrove ecosystem consists of organisms (plants and animals) interacting with environmental factors in a mangrove habitat (Vermeiren et al., 2015; Onyena and Sam 2020).

One of the organisms that live in the mangrove area is Crustacea. Crustacea, such as crabs, are macrobenthic animals associated with mangroves. Ecologically, mangrove areas have high productivity to support the surrounding environment because they are rich in nutrients with optimum temperature, $\mathrm{pH}$, oxygen, and salinity and calm water conditions so that they are suitable for crab habitat (Sen et al. 2014; Alvareza and Leilani 2020). Crabs eat suspended matter (filter feeders), eat mangrove litter and fresh mangrove leaves, and are generally dominant on 
sandy and muddy substrates.

The presence of crabs is an essential indicator in the mangrove ecosystem (Freitas et al., 2021). This is because crab has an important role ecologically and economically. The ecological part of crabs in the mangrove ecosystem includes converting nutrients and enhancing mineralization, increasing the distribution of oxygen in the soil, helping the carbon life cycle, and providing natural food for various species of aquatic biota. Crab also has a high economic value because humans can sell it as a high protein food ingredient. In addition, according to Ginantra et al. (2021), the presence of crabs in the mangrove ecosystem can also be useful as an additional attraction for ecotourism activities.

Ecotourism activities in mangrove areas, in principle, are the use of mangrove areas while maintaining the biological/ecological functions of mangrove areas that have social and economic value for local communities (Duangjai et al., 2014). The conservation of mangrove areas and the ecotourism business are highly dependent on the diversity of animals and plants that live in them (Hakim et al., 2017). Ecotourism can be used as a conservation measure to protect mangrove areas and the organisms that live in them, such as crabs. A mangrove ecosystem that is used as ecotourism will increase conservation and reduce things that damage mangrove areas, such as (i) felling of mangrove trees, (ii) conversion into fish and shrimp farming pond areas, land clearing for settlements or agricultural areas, and (iii) landfills or toxic waste. The degradation of the mangrove area causes changes in the composition and structure of mangrove vegetation, destroys the balance of ecosystems and habitats (physical and chemical environmental factors), as well as the extinction of species of organisms, such as crabs (Nowak 2013).

The mangrove area in Pacitan District is quite extensive and spread over several points, such as Teleng Ria Beach, Siwil Beach, and Grindulu Beach. Research that has been conducted on the species of mangrove trees in the Pacitan mangrove area is dominated by Rhizophora mucronata, Avicennia alba, Sonneratia alba, Nypa fruticans, Avicennia marina, which are the result of planting (Setyawan et al. 2002). Mangrove areas in Pacitan District are generally not polluted, and the land has the potential to grow mangrove plants (Pacitan District Marine and Fisheries Service 2014). This area has a coastline of 70,709 $\mathrm{km}^{2}$ (Central Bureau of Statistics of Pacitan District 2021), which can be a mangrove area for ecotourism management in Indonesia.

It is very important to research crab diversity in the mangrove area because it will improve the quality of mangroves and potentially support ecotourism in the Pacitan mangrove ecosystem. The diversity, abundance, morphology, activity, number of individuals, and distribution of each crab species will interest tourists. In addition, research data on crab diversity has never existed in Pacitan. Therefore, this study aims to determine the diversity of crabs and their potential to support ecotourism if Teleng Ria Beach, Grindulu Beach, and Siwil Beach, Pacitan, East Java, Indonesia, will be used as ecotourism in the future. It is hoped that this data can be a reference for managers of mangrove areas in developing ecotourism and efforts to conserve mangrove forests.

\section{MATERIALS AND METHODS}

\section{Study area}

This research was conducted on November 2021 at three coastal locations with mangrove ecosystems: Teleng Ria and Grindulu Beach in Pacitan Sub-district and Siwil Beach in Ngadirojo Sub-district, Pacitan District, East Java, Indonesia (Table 1). Apart from having a mangrove ecosystem, the three locations were chosen because of their proximity and affordable access (Figure 1).

\section{Sampling technique}

Twenty-five plots measuring $10 \mathrm{~m}$ x $10 \mathrm{~m}$ at each study site have been created. Plot selection was based on the different substrates in each location. After that, the species and number of crabs in each plot were counted and recorded. Then, abiotic environmental factors such as air, water and soil temperature, water and soil $\mathrm{pH}$, and water salinity were made. Then, this study also recorded the dominant tree mangrove species in each research location. Finally, crab retrieval is done using a handpicking technique, a net tool, and a shovel to dig into the ground the crabs are hiding. The caught crabs were then put into bottles and given alcohol $(70 \%)$ before being identified.

\section{Crab identification and activity}

Identification was carried out based on the morphological characteristics of crabs such as shell color, claw shape, body color, and body size. Identification refers to Shih and Suzuki (2016), Lapolo et al. (2018), and Ginantra et al. (2021). This identification was carried out at the Laboratory of Animal Taxonomy, Faculty of Mathematics and Natural Sciences, Universitas Sebelas Maret, Surakarta, Indonesia.

Crab activity was observed directly by observing and documenting all activities at each research location. Each crab activity will be recorded, such as entering the water, entering the hole, walking on rocks, walking on the substrate, foraging for food, and other activities. Crab activity was observed for approximately 2 hours at each research location.

\section{Data analysis}

The data obtained were processed using the ShanonWiener diversity index, evenness, Simpson dominance, and the abundance of each location and the total research location. The analysis of the existence of crabs as a support ecotourism appeal refers to Rahmila and Halim (2018) and Ginantra et al. (2021).

\section{Shanon-Wiener diversity indeks}

$H^{\prime}=-\sum$ pi $\times \ln$ pi

Where:

H': Diversity index of Shannon-Winner

$\mathrm{Pi}$ : The number of individuals of a species divided by the total number of species.

$\ln$ : The number of individuals of the type. 
The criteria for the diversity index are $\mathrm{H}^{\prime}<1.5$; then the species diversity is low; $1.5<\mathrm{H}^{\prime}<3.5$ means that the species diversity is moderate; and $\mathrm{H}^{\prime}>3.5$, then the species diversity is high.

The evenness index $(E)$

$$
E=\frac{H^{\prime}}{\ln (S)}
$$

Where:

E : Specific evennes index

H': diversity index of Shannon-Winner

ln: Natural logarithm

S: Number of species Found
The criteria for the diversity index are $0<\mathrm{E}<0.4$, then the evenness is low, community depressed; $0.4<\mathrm{E}<0.6$ means that the evenness is moderate, community labile; $0.6<\mathrm{E}<1.0$ then the evenness is high, and community stable.

Simpson dominance index

$$
\mathrm{D}=\Sigma_{1}^{\mathrm{S}} \frac{\mathrm{ni}(\mathrm{ni}-1)}{\mathrm{N}(\mathrm{N}-1)}
$$

Where :

D: Dominance index

ni: The number of individual species to the-i

$\mathrm{N}$ : The number of individuals of all species

The dominance index ranges from 0 to 1 , where the smaller the value of the dominance index indicates that there are no dominant species.
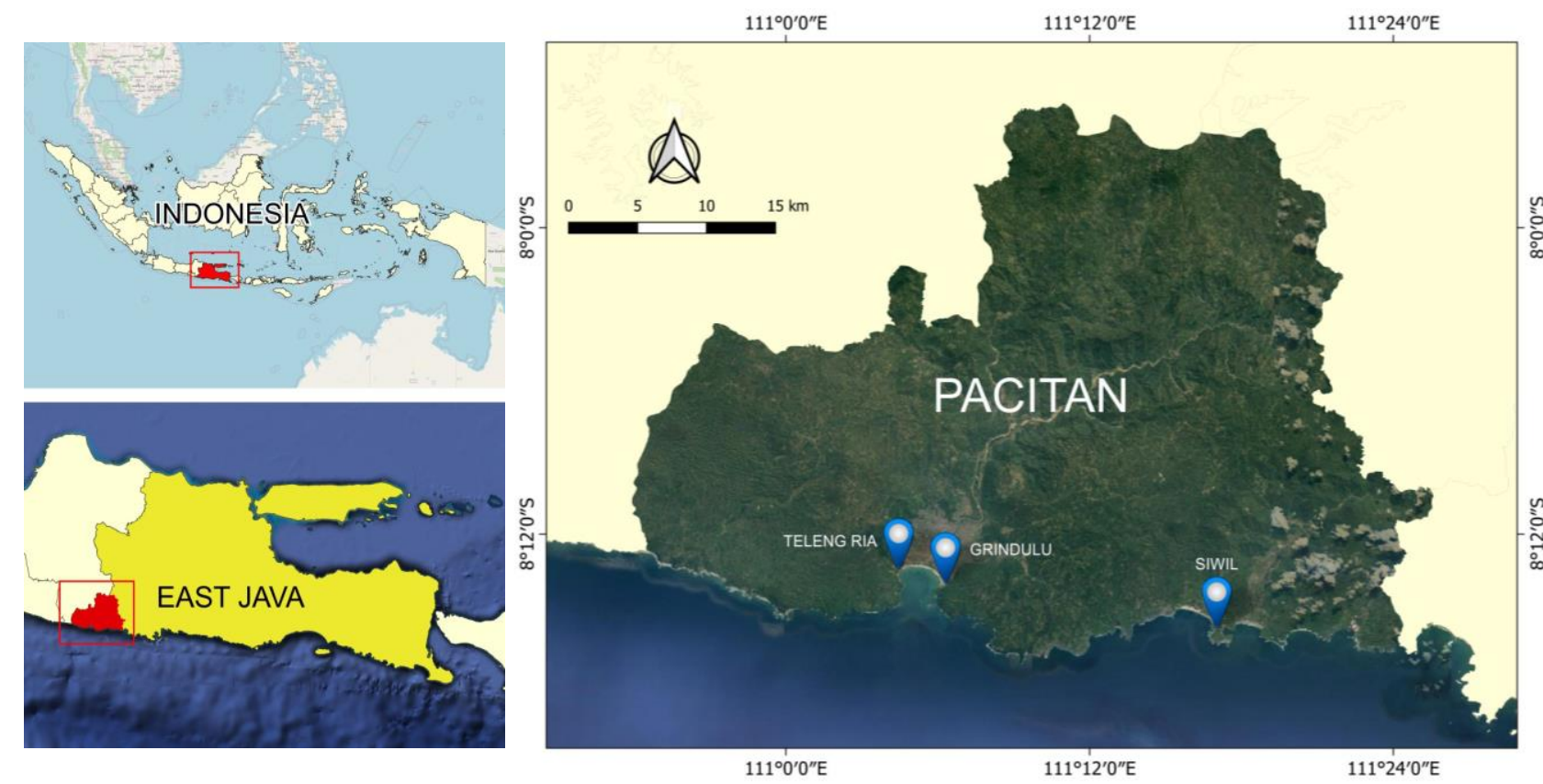

Figure 1. The location of the research crabs mangrove ecosystem in Teleng Ria, Grindulu and Siwil Beach, Pacitan, East Java, Indonesia

Table 1. Coordinates, type of subtracts, type of mangrove vegetation, and description of the location study (Teleng Ria, Grindulu and Siwil Beach, Pacitan, East Java, Indonesia)

\begin{tabular}{lllll}
\hline Location & Coordinates & $\begin{array}{l}\text { Type of } \\
\text { Substrate }\end{array}$ & $\begin{array}{l}\text { Dominant mangrove } \\
\text { vegetatation }\end{array}$ & Description \\
\hline Teleng Ria & $\begin{array}{l}\text { S } 08^{\circ} 13^{\prime} 19.63^{\prime \prime} \\
\text { E } 111^{\circ} 04^{\prime} 28.82^{\prime}\end{array}$ & Sandy, muddy & Avicennia alba & $\begin{array}{l}\text { It is a river mouth but not too close to the beach, } \\
\text { fishing piers, residential areas. }\end{array}$ \\
Grindulu & $\begin{array}{l}\text { S } 08^{\circ} 13^{\prime} 55.75^{\prime \prime} \\
\text { E } 111^{\circ} 06^{\prime} 21.42^{\prime \prime}\end{array}$ & Sandy, muddy & Rhizophora stylosa & $\begin{array}{l}\text { Close to beach. Mangrove conservation area is still } \\
\text { under development. It is evident from the number of } \\
\text { mangrove plant seeds planted. }\end{array}$ \\
Siwil & $\begin{array}{l}\text { S } 08^{\circ} 21^{\prime} 49.57^{\prime \prime} \\
\text { E } 111^{\circ} 07^{\prime} 67.15 ”\end{array}$ & $\begin{array}{l}\text { Sandy, rocky, } \\
\text { muddy }\end{array}$ & Sonneratia alba & $\begin{array}{l}\text { It is a river mouth but not too close to the beach. } \\
\text { Tidal area with sandy, muddy and rocky substrates }\end{array}$ \\
\hline
\end{tabular}




\section{RESULTS AND DISCUSSION}

\section{Crab diversity}

Mangrove forests on the coast of Pacitan, such as in Teleng Ria, Grindulu, and Siwil, have a specificity: most of the substrate is white sand/quartz sand, and rocky either in the form of rocks or fragments of dead coral. Sandy beaches generally have a higher temperature than muddy sand substrates because of the larger particle size; the water will not be retained for long and dry quickly. In addition, the organic matter content of white sand is also low, so not many biotas can survive in this habitat. However, at the research site, some rivers carry food and make several points of muddy sand habitat so that organisms such as crabs can still survive (Gray and Elliot 2009). The muddy sand will make it easier for the crabs to make holes, and the abundance of organic matter carried by the river flows for crab food.

This study found 5 species of crabs (Figure 2), namely Austruca annulipes (H. Milne-Edwards, 1837), Coenobita perlatus (H. Milne-Edwards, 1837), Ocypode kuhlii (De Haan, 1835), Perisesarma guttatum (A. MilneEdwards, 1869), and Scylla serrata (Forsskål, 1775). The species with the highest abundance was $O$. kuhlii, 0.33 ind $/ \mathrm{m}^{2}$, while $S$. serrata is a species with low abundance because only one individual was found in Siwil Beach. The crab diversity index was obtained for a total of three locations, including the medium category, with an index of 1.25. The family Ocypodidae is the most significant contributor to the number of species with two species (Table 2). The evenness of species is evenly distributed with a stable community structure as indicated by an evenness index of 0.78 and a low dominance index of 0.32 (Figure 3).

As for the diversity index at each location, the Siwil Beach research location has the highest diversity index, 1.3 (medium). The lowest diversity index is Grindulu Beach, 0.18 (lower). The number of species in a community and the abundance of each species will affect the diversity in an ecosystem. Diversity species in an ecosystem will decrease if there are fewer species and variations in the number of individuals of a species or several species with a more significant number of individuals. Compared to other locations, all species in this study can be found in Siwil Beach. This is related to the more diverse habitats in the Siwil Beach, whose habitat has a quartz/white sand substrate mixed with mud, sand with rocks, and sand with fragments of dead coral (Table 1).

The highest evenness index of crabs in Teleng Ria is 0.91 , and Siwil, which is 0.77 , is in the high category, indicating that the distribution of crabs in the area is relatively equal or even (Figure 2). The results of the dominance index in both places are the same, which is 0.32 . This indicates that the dominance of crab species in the area is low. The Grindulu area has a diversity index of 0.18 and an evenness index of 0.91 . Both values are low because only two species of crab were found. The crab $O$. kuhlii was dominant against $P$. guttatum in Grindulu. Compared to the other two locations, Grindulu does have a low and young mangrove tree density and size because the mangrove area is used as a mangrove nursery (Table 1). This condition will affect the canopy cover area and the organic matter produced. A wide and dense canopy cover will protect crabs from direct sunlight and predators' wave action and increase the production of organic matter produced (Ravichandran et al., 2011). The better vegetation from mangrove trees, the more diverse the crab species found.

\section{Factor abiotic}

A suitable living environment for crabs will make them survive and carry out their role as important organisms in the mangrove ecosystem. The environmental parameter values measured included temperature $\left({ }^{\circ} \mathrm{C}\right)$, acidity $(\mathrm{pH})$, and salinity (Table 3 ). The measurement of environmental parameters at the research site has average air, water, and soil temperature of $28-33{ }^{\circ} \mathrm{C}$. Compared with research in the Mangroves of Purworejo District, Central Java (Rahayu et al. 2018) and Kuala Langsa, Aceh (Putriningtias et al. 2019), the temperature parameters there are quite different, which is around $26-30^{\circ} \mathrm{C}$. However, the temperature of this study is not much different from research conducted in the mangrove forests of Alas Purwo National Park, East Java, 29-33 ${ }^{\circ} \mathrm{C}$ (Gita et al. 2015) and Segara Anakan Mangrove Forest Ecosystem, Cilacap, Central Java, 27-33 ${ }^{\circ} \mathrm{C}$ (Redjeki et al. 2017). According to Saparinto (2010), a suitable temperature for mangroves is not less than $20^{\circ} \mathrm{C}$, and in general, crabs that live in mangrove ecosystems can survive at temperatures of $23-33^{\circ} \mathrm{C}$. It is assumed that the difference in the average temperature of each location is influenced by the mangrove vegetation cover around it, the type of sediment, and the sampling time of the study.

Table 3. Abiotic factors in Teleng Ria, Grindulu and Siwil Beach, Pacitan, East Java, Indonesia

\begin{tabular}{|c|c|c|c|c|c|c|}
\hline \multirow{2}{*}{$\begin{array}{c}\text { Location } \\
\text { study }\end{array}$} & \multicolumn{3}{|c|}{ Temperature $^{\circ} \mathrm{C}$} & \multicolumn{2}{|c|}{ pH } & \multirow{2}{*}{ Salinity } \\
\hline & Air & Water & Soil & Water & Soil & \\
\hline Teleng Ria & 33 & 32,6 & 33 & 7,6 & 6 & 5 \\
\hline Grindulu & 32 & 32,5 & 33 & 8 & 7 & 10 \\
\hline Siwil & 32 & 28,2 & 31 & 7,6 & 6,1 & 5 \\
\hline
\end{tabular}

Table 2. Diversity and abundance of crabs crustaceans (ind. $/ \mathrm{m}^{2}$ ) in three location studies (Teleng Ria, Grindulu and Siwil Beach, Pacitan, East Java, Indonesia)

\begin{tabular}{|c|c|c|c|c|c|}
\hline \multirow{2}{*}{ Class/Family } & \multirow{2}{*}{ Species } & \multicolumn{3}{|c|}{ Location } & \multirow{2}{*}{ Total } \\
\hline & & Teleng Ria & Grindulu & Siwil & \\
\hline Malacostraca/Ocypodidae & Austruca annulipes & 0.01 & 0 & 0.19 & 0.2 \\
\hline Malacostraca/Coenobitidae & Coenobita perlatus & 0.02 & 0 & 0.03 & 0.05 \\
\hline Malacostraca/Ocypodidae & Ocypode kuhlii & 0.04 & 0.13 & 0.16 & 0.33 \\
\hline Malacostraca/Sesarmidae & Perisesarma guttatum & 0.02 & 0.01 & 0.09 & 0.12 \\
\hline Malacostraca/Portunidae & Scylla serrata & 0 & 0 & 0.001 & 0.001 \\
\hline
\end{tabular}




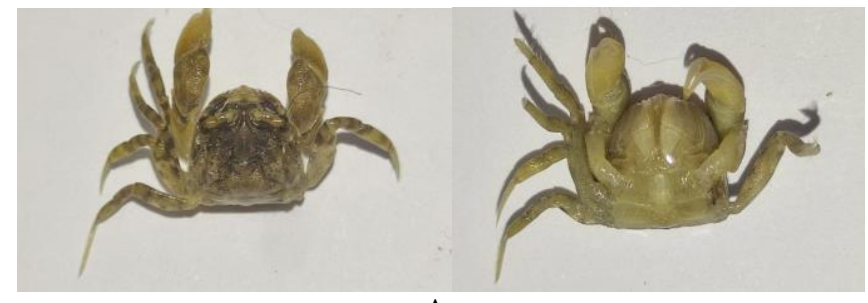

$\mathbf{A}$

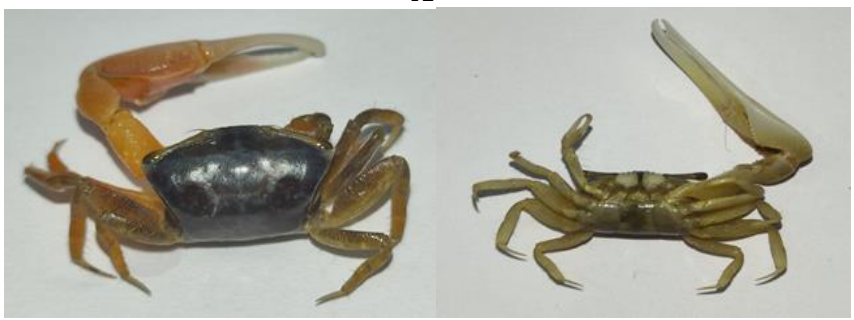

C

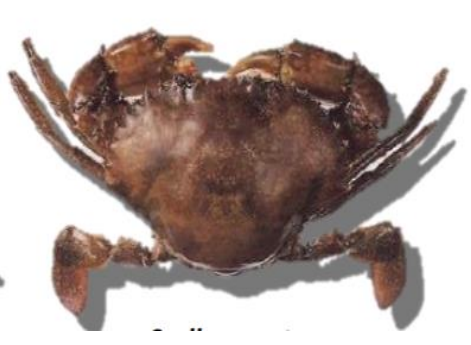

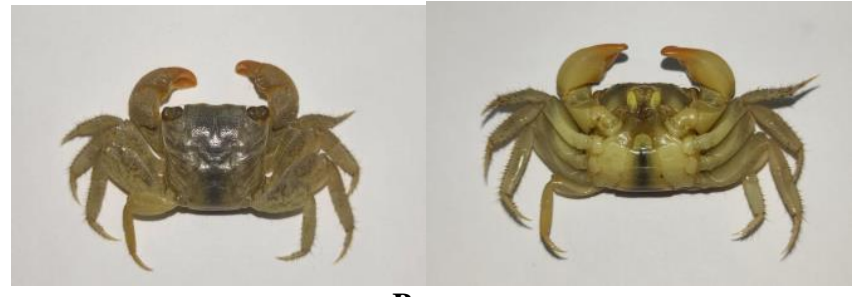

B

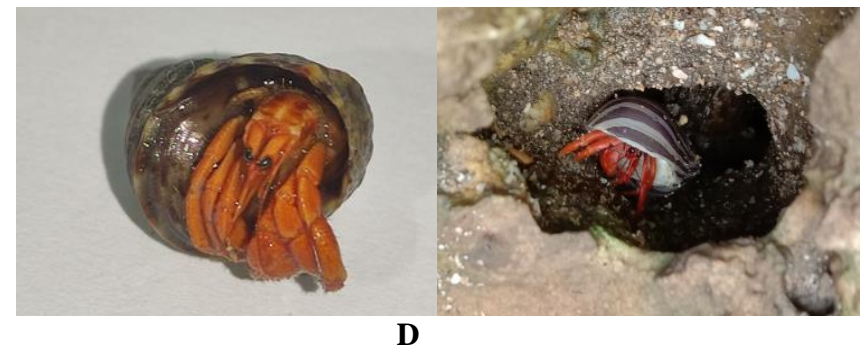

D

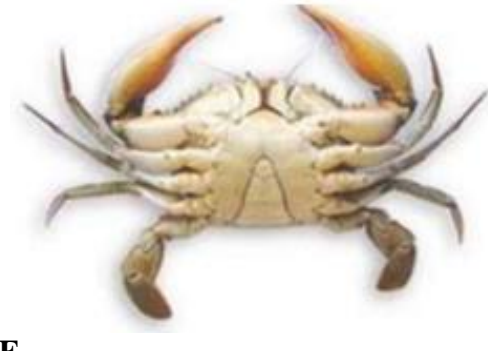

E

Figure 3. Species of Crustaceans in three location study (Teleng Ria, Grindulu and Siwil Beach, Pacitan, East Java, Indonesia): A. Ocypode kuhlii; B. Perisesarma guttatum; C. Austruca annulipes; D. Coenobita perlatus; E. Scylla serrata

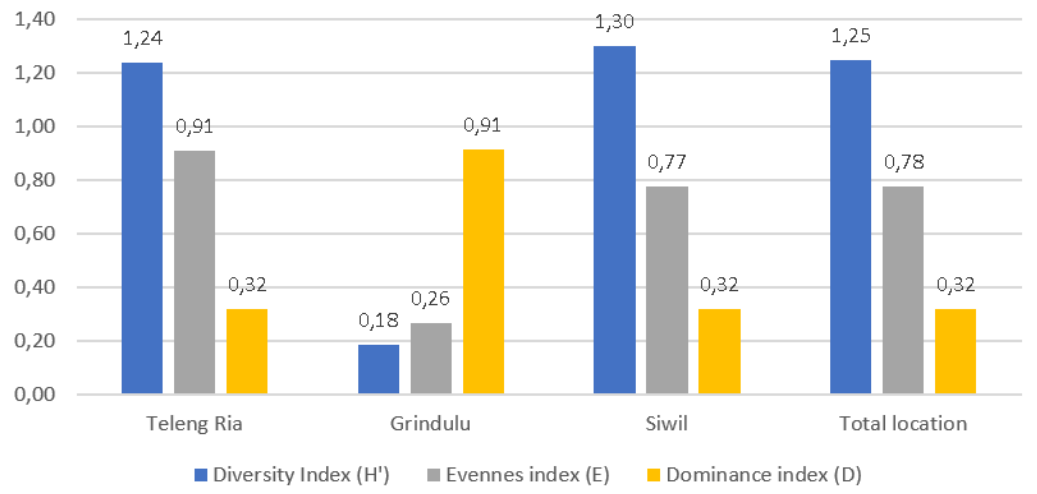

Figure 2. Diversity index, evenness index, and crab dominance index in three location studies (Teleng Ria, Grindulu and Siwil Beach, Pacitan, East Java, Indonesia)

The water and soil $\mathrm{pH}$ values at each location ranged from 6-8. This is still considered normal because, according to Gillikin et al. (2004), the normal $\mathrm{pH}$ value for brackish waters of mangrove ecosystems with animals and plants in them has a pH between 6-9. According to Pratiwi (2010), $\mathrm{pH}<5$ and $>9$ will create unfavorable conditions for macrozoobenthos life. This means that each research location is at a good $\mathrm{pH}$ for crab life and development. The $\mathrm{pH}$ value describes the balance between acid and base, which will affect the growth of mangroves. Good mangrove growth in the composition of the mangrove ecosystem will make the litter produced to meet the needs of crab food. The $\mathrm{pH}$ results in the crab habitat in this study were also the same as the $\mathrm{pH}$ results in the crab habitat by Gita et al. (2015), Redjeki et al. (2017), Rahayu et al. (2018), and Putriningtias et al. (2019).

Based on observational data, the average salinity obtained in the observation area is in the range of 5-10 ppt. According to Rahayu et al. (2018), the range is still in the range of oligohaline $(0.5-5 \mathrm{ppt})$ to mesohaline $(5-18 \mathrm{ppt})$ and can still support crab life. The highest salinity of around $10 \mathrm{ppt}$ is found in Grindulu. This is because Grindulu is closer to the coast, so seawater has more influence than freshwater (Table 1). Meanwhile, the lowest salinity range of $5 \mathrm{ppt}$ was found in Siwil and Teleng Ria. This is because the location is far from the beach, so the 
seawater has less direct effect. On the other hand, freshwater has more influence because the mangrove areas in both locations receive more freshwater input from water channels, resulting in water dilution resulting in relatively lower salinity than in Grindulu. Based on the research, the water's salinity in the mangrove area's study area fluctuates and is influenced by freshwater runoff from the mainland and the entry of seawater from river mouths.

\section{Crab potential as a support ecotourism attraction}

According to Ginantra et al. (2021), information about the species of crabs found their status of existence, whether protected or not, rare or common, is important information to support the attractiveness of ecotourism. In addition, the morphology, activity, number, and distribution of each crab species in an ecotourism area has its own uniqueness and will increase the attractiveness of tourists to visit.

\section{Unique activities of crabs as supporting ecotourism attractions}

Activities in the habitat by crabs were observed, such as walking on rocks, sand/gravel, entering and exiting hiding holes, getting into mud, foraging for food, and walking on mudflats. The behavioral observations must be made carefully, because they perfectly camouflage with their environment (Figure 4). This activity is an attraction crab's that tourists can see. Ocypode kuhlii and P. guttatum will be easy to find and see by tourists because they often walk on sand or rocks. Then, the hermit crab C. perlatus runs slower than $O$. kuhlii and $P$. guttatum to be held and observed for longer by tourists. The most exciting activity of the crabs encountered was the activity of $A$. annulipes. Austruca annulipes have activities such as dancing and playing the violin, where the male often moves his giant claw in the air while one of the smaller claws picks up food on the substrate. In the observations made, this activity was carried out at low tide during the day while looking for food (see the youtube video of this research https://youtu.be/QNFR0hKYPZ8). The results of observations of other activities regarding the $\operatorname{crab} A$. annulipes that this crab is very sensitive to vibration, if there is a vibration around this crab, then this crab quickly goes into its hiding hole. As long as when seeing this crab, do not make vibration around its hiding hole, then this crab will come out and dance again so the tourists can see this crab dance closely and clearly. In many plots in Siwil Beach, this dance activity is carried out by dozens of individuals of $A$. annulipes under the shade of Rhizophora stylosa and Sonneratia alba trees. Then, the activity of $S$. serrata crabs is rather difficult to observe during the day because these crabs are nocturnal (Febriyani 2018) and always hide in their hiding holes.

\section{Unique morphology of crabs as supporting ecotourism attractions}

Austruca annulipes. Morphologically, according to Rahayu et al. (2018) the crab A. annulipes has a body size of 25-60 mm, has a trapezoidal carapace shape with white spots that cross close to the anterior and is black, orbits are not visible, cerpus, merus, and manus are red, smooth dactyl and pollex are white. The carapace has 1 or 2 dark bands on the back. Pollex's large claws have a tubercle along the underside. The upper side of the dactyl is completely convex, especially the mid-flat. Gonopod with less torque. The posterior flange is longer and wider than the anterior. In males, this crab has a characteristic claw that is larger than other claws. The paws are red-orange or yellow and the carapace is black with blue spots. Based on their small size, a pair of claws that are very different in size and attractive colors make these crabs very attractive to tourists.

Coenobita perlatus. The $C$. perlatus is a species of land hermit crab. According to Pavia (2006), this crab is known as the strawberry hermit crab because of its reddish-orange color in the body. In addition, the entire body of this type of hermit crab is also filled with white granules (pores) which is the reason why it is also called "strawberry". The adults can grow to a typical length of $80 \mathrm{~mm}$ (3.1 in) and weigh $80 \mathrm{~g}$. Eye color is generally clear brown, but sometimes found black, moss green, or gray eyes. The abdomen of this hermit crab is always pure white and the carapace on the back tends to widen. The $C$. perlatus utilize empty shells of Mollusca to protect its abdomen (Jeremy and Patria 2020). The third left leg, which is usually called the shield leg is useful for closing the shell with the slightly fat left pincer, while the left pin is round and flat. Because C. perlatus which has a reddish-orange color also filled with white granules (pores) in the body like a strawberry and has a house/shell of a Mollusca that is attractively colored and has a unique shape so that it can be an attraction for tourists to see.

Ocypode kuhlii. According to Sakai and Türkay (2013) and Amin et al. (2021), this crab is small in stature and the carapace is $33 \times 43 \mathrm{~mm}$. Carapace is wider than long; convex in the direction of its length; fine nodules. This crab has a square eye shape with a pair of eyes that rise upwards. The first limb is calf-shaped, which is unequal in size between the right and left; the surface texture is speckled. The head of the calf (palm) with a rounded top side and rough nodules; inner side with middle (8-10) nodules lined crosswise, bidirectional, stiff scraper to produce a whooshing sound. The morphology of this crab is small, has fine nodules, not large claws and unique eyes make this crab very adorable for tourists to see.

Perisesarma guttatum. This crab has a body shape (carapace) that is almost square. Carapace is about $3 \mathrm{~cm}$ in length. This crab has a pair of claws that are reddish in color with bright orange internal palms. The body surface also has protrusions like that of $P$. darwinensis, but does not have a striped pattern on the legs (Fauzan et al. 2020). In the present study, different types of pectinated crests (on the dorsal face of chelar palm) were recognized among the selected species of the family Sesarmidae. Males of this species have two rows of transverse crests with elevated teeth, each row (crest) being framed by a high and large tubercle on the inner side (Shahdadi and Schubart 2017). The morphological characteristics of the carapace shape and the color of the claws of this crab make this crab attractive for tourists to see. 


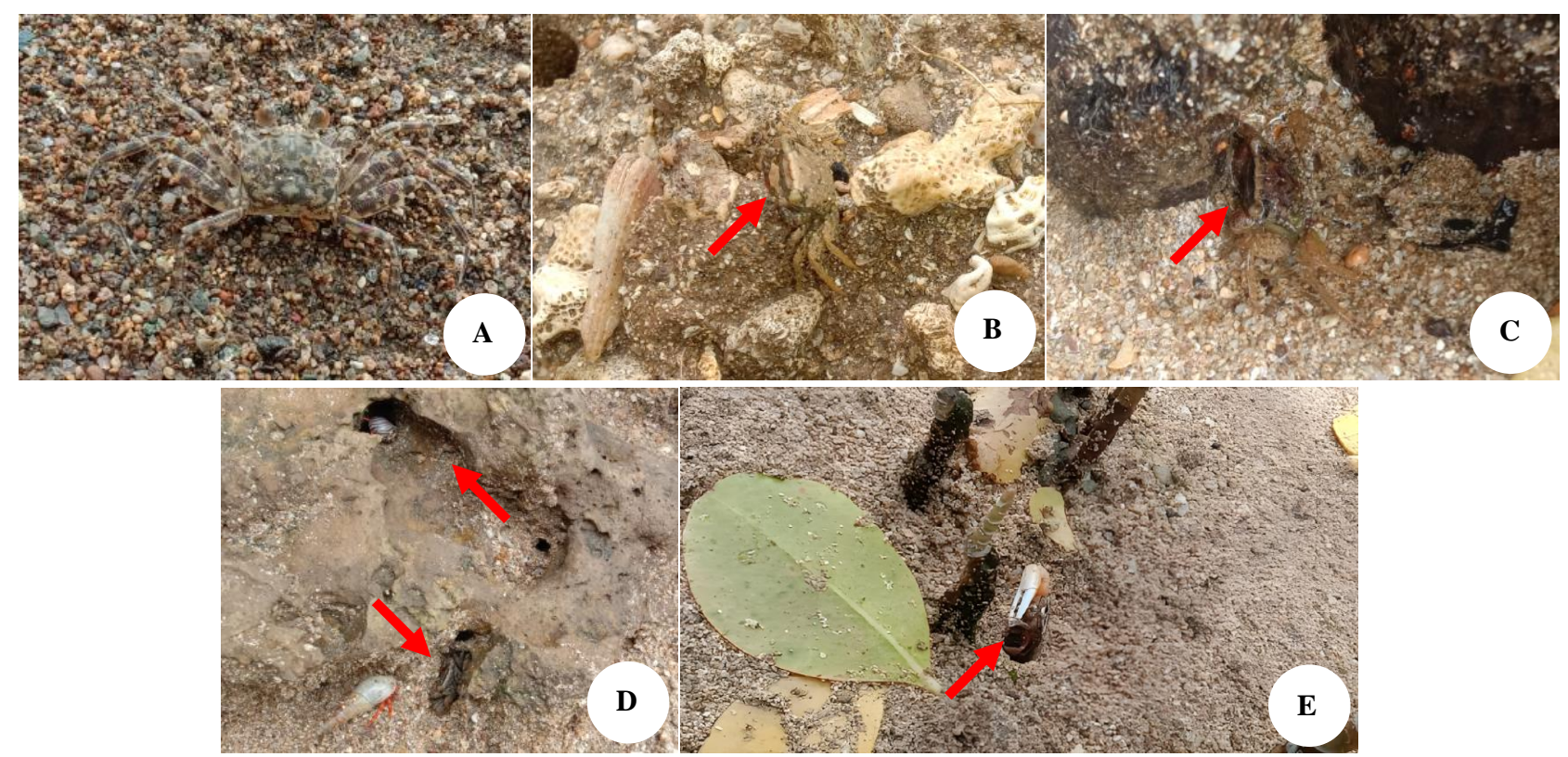

Figure 4. Some crabs activity in three location studies (Teleng Ria, Grindulu and Siwil Beach, Pacitan, East Java, Indonesia): A. Ocypode kuhlii walking on sand; B and C. Perisarma guttatum walking on the rocks; D. Coenobita perlatus and Perisesarma guttatum walking towards hiding in a rock crevice; E. Austruca annulipes to a hiding hole in the sand

Scylla serrata. According to Febriyani (2018), the characteristics of $S$. serrata crabs are that they have a slightly greenish, olive-green to almost black carapace, while the outer side of the claws is green, often with a spotted pattern or spots. On the frontal side, there are 4 sharp spines, the outer palm (claws) is green with a round pattern, has three pairs of walking legs and one swimmer's leg which is located at the end of the abdomen with the ends equipped with a rower. The last pair of legs (swimming legs) have spots, both in males and females. These crabs are large to very large, the maximum carapace width is between $25-28 \mathrm{~cm}$ and the weight reaches $2-3 \mathrm{~kg}$. Compared to other crabs found in this study, this crab has a large body size, carapace and claws that make this crab have special characteristics that attract tourists to see it.

Number of individuals and distribution of crabs in research study as supporting ecotourism attractions

Twenty-five plots spread over three research sites, found 5 species of crab with a total of 613 individuals (Table 4). From the number of individuals, it is evidence that the three locations are suitable habitats for several species of crabs. Crabs are one of the Crustacea that live in coastal/mangrove ecosystems and are one of the key species that have a very important role in maintaining the balance of the ecosystem. Therefore, the presence of crabs in the mangrove ecosystem can be used to indicate whether the mangrove ecosystem is still functioning properly or not. According to Kristensen et al. (2012), Saher and Qureshi (2014), and Kalor et al. (2018) crab is a key species in mangrove forests that functions to convert nutrients and enhance mineralization, increase oxygen distribution in the soil, assist in the carbon cycle, and provide natural food for various species of biota in the waters.
Table 4. Total individual crabs in Teleng Ria, Grindulu and Siwil Beach, Pacitan, East Java, Indonesia

\begin{tabular}{|c|c|c|c|c|}
\hline \multirow[b]{2}{*}{ Species } & \multicolumn{3}{|c|}{$\begin{array}{l}\text { Location } \\
\end{array}$} & \multirow{2}{*}{$\begin{array}{c}\text { Total } \\
\text { individul } \\
\text { spesies }\end{array}$} \\
\hline & $\begin{array}{c}\text { Teleng } \\
\text { Ria }\end{array}$ & Grindulu & Siwil & \\
\hline Austruca annulipes & 9 & 0 & 189 & 198 \\
\hline Coenobita perlatus & 18 & 0 & 33 & 51 \\
\hline Ocypode kuhlii & 38 & 64 & 156 & 258 \\
\hline Perisesarma guttatum & 17 & 3 & 85 & 105 \\
\hline Scylla serrata & 0 & 0 & 1 & $\begin{array}{c}1 \\
613\end{array}$ \\
\hline
\end{tabular}

In this study, $O$. kuhlii were found in all study sites with the highest abundance (Table 2). According to Elfandi et al. (2018) O. kuhlii spread in many parts of Indonesia such as Sumatra, Java, Madura, Bali, Lombok, Flores, and Papua. The existence of this crab population is strongly influenced by the condition of the beach which is its habitat. Unspoiled beaches are usually found in an abundance of these crabs because the food chain process is still maintained. Polluted beaches will rarely be found $O$. kuhlii (Schlacher et al. 2011).

Besides $O$. kuhlii, $P$. guttatum can also be found in all research sites, this species likes muddy sand habitats in each research location, eating vascular plants including mangrove litter and young sprouts. These crabs can live on the surface of the mud, or mangrove trees can tolerate a wide range of salinity, which causes this crab to dominate in mangrove forests. This is also in accordance with the research conducted by Shih et al. (2016), Lapolo et al. (2018) and Rosenberg (2019) that crabs from the Ocypodidae (O. kuhlii and A. annulipes) and Sesarmidae 
(P. guttatum) groups are commonly found in inhabiting shorelines worldwide across the tropics and well into the temperate zones mangrove forests in Indonesia. These three species are often found in vents with stable temperatures and can adapt to their surrounding environment even in damaged or extreme conditions.

Coenobita perlatus lives in a wide swathe of the IndoPacific, like Indonesia (Mckenzie 1999). From the research conducted, it was found that most $C$. perlatus individuals were found in Siwil Beach. Ceonobita perlatus likes substrate conditions that are dominated by sandy and rocky substrates (Ingle 1993). Hermit crab can be used as an environmental bioindicator. If there are hermit crabs, the environment is still good and far from environmental pollution (McKenzie 1999). In addition, C. perlatus can be eaten by people, however, they are more usually found as home pets. Because they are scavengers, they also play an important part in beach cleanup. Hermit crabs are important in keeping the beach clean and creating a healthy environment for humans and other aquatic and coastal species by removing dead sea matter and other detritus that collects on the shore (McKenzie 1999).

In this study, $S$. serrata is a species that has few individuals and is only found on Siwil Beach. According to Ginanthra et al. (2021) several factors that can cause the low population of this crab include substrate, mangrove plants, seagrass, and human disturbance. In addition, according to Febriyani (2018), the S. serrata crab is a typical species in the mangrove area. These crabs only come out of hiding some time after sunset and move throughout the night mainly in search of food. When the sun is about to rise, these crabs immerse themselves again, so these crabs are classified as nocturnal animals. This species is edible and susceptible to hunting by humans. Crabs have a relatively stable habitat. Li et al. (2015) showed that the distribution of crabs has a significant correlation with energy flow and species because each crab responds to feed on different mangrove vegetation. This species was found in the white sand substrate with $R$. stylosa and $S$. alba vegetation. Mangrove vegetation that grows will provide nutrition and food for crabs. Kamaruddin et al. (2019) also found that the crab S. serrata is found on the sandy substrate in mangrove habitat in Sungai Pinang Village, Lingga and this species also were found in muddy sediments, Cibako mangrove forest, Garut, West Java by Avianto et al. (2013) and in the mangrove forests of Alas Purwo National Park, East Java by Gita et al. (2015).

The conclusion of this study was found 5 species of crabs, namely $A$. annulipes, $C$. perlatus, $O$. kuhlii, $P$. guttatum, and S. serrata. The crab diversity index was obtained for a total of three locations including the medium category with an index of 1.25 (medium). Morphology, activity, number of individuals, and distribution of each crabs species in an ecotourism area will increase the attractiveness of tourists to visit. It is hoped that this data can be a reference for managers of mangrove areas in developing ecotourism and efforts to conserve mangrove forests.

\section{ACKNOWLEDGEMENTS}

Thanks to Pacitan District for allowing this research to be carried out. We also thank all colleagues for supporting the writing of this paper and fruitful comments from anonymous reviewers. Hopefully, this review can benefit both the authors and readers.

\section{REFERENCES}

Amin F, Darus SJP, Medy O, Desy MHM, Farnis BB, Ockstan K. 2021. Identifikasi morfologi dan keanekaragaman kepiting pada timbunan berbatu di Pantai Pesisir Malalayang Dua Kota Manado. J Pesisir dan Laut Tropis 9 (3): 123-132. [Indonesian]

Alvareza M, Leilani I. 2020. Community structure of the mangrove forest in the tourism area of Pariaman City, West Sumatra. Bioscience 4 (1): 62-72. DOI: 10.24036/0202041108192-0-00.

Avianto, Sulistiono, Setyobudiandi I. 2013. Habitat characteristics and potency of mud crabs Scylla serrata, S. transquaberica, and $S$. olivacea in Cibako Mangrove Forest, Garut District, West Java. Bonorowo Wetlands 3: 55-72. DOI: 10.13057/bonorowo/w030201.

Badan Pusat Statistik Kabupaten Pacitan. 2021. Garis pantai Pacitan. Badan Pusat Statistik Kabupaten Pacitan, Jawa Timur, Indonesia. [Indonesian]

Dinas Kelautan dan Perikanan Kabupaten Pacitan. 2014. Data Kawasan Mangrove. Dinas Kelautan dan Perikanan Kabupaten Pacitan, Jawa Timur. [Indonesian]

Duangjai W, Tuntates U, Kroeksakul P. 2014. The Comparative evaluation of community-based ecotourism management at mangrove forest communities in Satun Province, Thailand. Intl J Emerg Technol Adv Eng 4 (6): 42-48.

Elfandi T, Adi W, Syari IA. 2018.. Density of ghost crab (Ocypode) at Batu Bedaun Beach and Air Anyir Beach of Bangka Regency. Akuatik Jurnal Sumberdaya Perairan 12 (1): 10-17. DOI: 10.33019/akuatik.v12i1.686.

Fauzan N, Soendjoto MA, Zaini M. 2020. Kepadatan dan keragaman kepiting Di Kawasan Ekowisata Mangrove Pagatan Besar, Kabupaten Tanah Laut, Indonesia. Enviro Scienteae 16 (2): 287-295. DOI: 10.20527/es.v16i2.9660. [Indonesian]

Freitas Jr F, Pescinelli RA, Costa RC, Hilesheim JC, Dieh FL, Branco JO. 2021. Brachyuran crab diversity across spatial and temporal scales in a mangrove ecosystem from the western Atlantic. Reg Stud Mar Sci 43 (2021): 1-8. DOI: 10.1016/j.rsma.2021.1017032.

Febriyani F. 2018. Distribusi Spasial dan Temporal Kepiting (Scylla sp.) Di Ekosistem Mangrove Wilayah Tapak Kelurahan Tugurejo Kota Semarang. [Skripsi]. Jurusan Biologi, Universitas Negeri Semarang. [Indonesian]

Gillikin DP, de Wachter B, Tack JF. 2004. Physiological responses of two ecologically important Kenyan Mangrove crabs exposed to altered salinity regimes. J Exp Mar Bio Ecol 301 (1): 93-109. DOI: 10.1016/j.jembe.2003.09.024.

Ginantra IK, Muksin IK, Joni M. 2021. Crab diversity as support for ecotourism activities in Pejarakan Mangrove Forest, Buleleng, Bali, $\begin{array}{llll}\text { Indonesia. } & \text { Biodiversitas } 22 \text { 4139-4145. }\end{array}$ 10.13057/biodiv/d221003.

Gita RSD, Sudarmadji, Waluyo J. 2015. The effect of abiotic factors on the diversity and abundance of mud crab (Scylla spp.) in mangrove forests of Alas Purwo National Park, East Java. Bonorowo Wetlands 5: 11-20. DOI: 10.13057/bonorowo/w050102.

Gray JS, Elliot M. 2009. Ecology of Marine Sediments from Science to Management, 2nd ed. Oxford University Press, London. DOI: 10.1093/oso/9780198569015.003.0005.

Hakim L, Siswanto D, Nakagoshi N. 2017. Mangrove conservation in East Java: The ecotourism development perspectives. J Trop Life Sci 7 (3): 277-285. DOI: $10.11594 /$ jtls.07.03.14.

Ingle R. 1993. Hermit Crabs of the Northeastern Atlantic Ocean and the Mediterranean Sea. Chapman \& Hall: Natural History Museum Publications, London.

Jeremy Y, Patria MP. 2020. Strawberry hermit crab (Coenobita perlatus, H. Milne Edwards, 1837) gastropod shell utilization pattern according to the type and size. AIP Conf Proc 2242: 1-5. DOI: $10.1063 / 5.0008042$ 
Junk WJ, Piedade MTF, Lourival R, Wittmann F, Kandus P, Lacerda LD, Bozelli RL, Esteves FA, da Cunha CN, Maltchik L, Schöngart J, Schaeffer-Novelli Y, Agostinho AA. 2014. Brazilian wetlands: Their definition, delineation, and classification for research, sustainable management, and protection. Aquat Conserv Mar Freshw Ecosyst 24: 5-22. DOI: $10.1002 / \mathrm{aqc} .2386$.

Kainuma M, Baba S, Oshiro N, Kezuka M, Chan HT. 2013. Current status of mangroves worldwide. Middle East 624: 0-4.

Kamaruddin E, Siregar YI, Saam Z, Sukendi. 2019. Diversity and abundance of Scylla spp. in mangrove habitat at Sungai Pinang village, Lingga. Biodivers Intl J 3 (6): 235-239. DOI: 10.15406/bij.2019.03.00150.

Kristensen E, Penha-Lopes G, Delefosse M, Valdemarsen T, Quintana C, Banta G. 2012. What is bioturbation? The need for a precise definition for fauna in aquatic sciences. Mar Ecol Prog Ser 446: 285 302. DOI: 10.3354/meps09506.

Lapolo NR, Utina D, Wahyuni, Baderan K. 2018. Diversity and density of crabs in degraded mangrove area at Tanjung Panjang Nature Reserve in Gorontalo, Indonesia. Biodiversitas 19 (3): 1154-1159. DOI: 10.13057/biodiv/d190351.

Li W, Cui L, Zhang M, Wang Y, Zhang Y, Lei Y, Zhao X. 2015. Effect of mangrove restoration on crab burrow density in Luoyangiang Estuary China. For Ecosyst 2 (1): 1-9. DOI: 10.1186-s40663-015-0046-3.

McKenzie N. 1999. Coenobita perlatus. Animal Diversity Web.

Nowak K. 2013. Mangrove and peat swamp forests: Refugehabitats for primates and felids. Folia Primatologica 83: 361-376. DOI: 10.1159/000339810.

Onyena AP, Sam K. 2020. A review of the threat of oil exploitation to mangrove ecosystem: Insights from Niger Delta, Nigeria. Glob Ecol Conserv 22: 1-12. DOI: 10.1016/j.gecco.2020.e00961.

Pavia A. 2006. What is a Hermit Crab? Healthy Pet (2nd ed). John Wiley and Sons, US.

Pratiwi R. 2010. Asosiasi Krustasea di Ekosistem Padang Lamun Perairan Teluk Lampung. J Ilmu Kelautan 15 (2): 66-76. [Indonesian]

Putriningtias A, Teuku MF, Siti K, Syamsul B, Helmy A. 2019 Keanekaragaman jenis kepiting di Ekosistem Hutan Mangrove Kuala Langsa, Kota Langsa, Aceh. J Biologi Tropis 19 (1): 101-107. DOI: 10.29303/jbt.v19i1.1074. [Indonesian]

Rahayu SM, Wiryanto, Sunarto. 2018. Keanekaragaman kepiting biola di Kawasan Mangrove Kabupaten Purworejo, Jawa Tengah. Bioeksperimen 4(1): 53-63. DOI: 10.23917/bioeksperimen.v4i1.5933. [Indonesian]

Rahmila YI, Halim MAR. 2018. Mangrove forest development determined for ecotourism in Mangunharjo Village Semarang. E3S Web Conf 73: 04010. DOI: 10.1051/e3sconf/20187304010.
Ravichandran S, Fredrick WS, Khan SA, Balasubramanian T, 2011. Diversity of mangrove crabs in South and Southeast Asia. J Oceanogr Mar Environ Syst 1 (1): 01-07.

Redjeki S, Arif M, Hartati R, Pinandita LK. 2017. Kepadatan dan persebaran kepiting (Brachyura) di Ekosistem Hutan Mangrove Segara Anakan Cilacap. J Kelautan Tropis November 20 (2): 131139. DOI: 10.14710/jkt.v20i2.1739. [Indonesian]

Rosenberg MS. 2019. A fresh look at the biodiversity lexicon for fiddler crabs (Decapoda: Brachyura: Ocypodidae). Part 1: Taxonomy. J Crustac Biol 39 (6): 729-738. DOI: 10.1093/jcbiol/ruz057.

Saher NU, Qureshi NA. 2014. Food and feeding ecology of fiddler crabs species found along the coast of Pakistan. Rom J Biol Zool 59: 35-46.

Sakai K. Türkay M. 2013. Revision of the genus Ocypode with the description of a new genus, Hoplocypode (Crustacea: Decapoda: Brachyura). Mem Queensl Mus Nat 56 (2): 665-793.

Saparinto C. 2010. Usaha Ikan Konsumsi di Lahan $100 \mathrm{~m}^{2}$. Penebar Swadaya, Jakarta. [Indonesian]

Schlacher TA, Jager RD, Nielson T. 2011. Vegetation and ghost crabs in coastal dunes as indicators of putative stressors from tourism. Elsevier (11) : 284-294. DOI: 10.1016/j.ecolind.2010.05.006.

Sen S, Mukherjee S, Chaudhuri A, Homechaudhuri S. 2014. Temporal changes in brachyuran crab diversity along heterogeneous habitat in a mangrove ecosystem of Indian Sundarbans. Sci Mar 78: 433-442. DOI: $10.3989 /$ scimar.03931.04A.

Setyawan AD, Susilowati A, Wiryanto. 2002. Relics habitat of mangrove vegetation in south coast of Java. Biodiversitas 3 (2): 242-256. DOI: 10.13057/biodiv/d030206.

Shahdadi A, Schubart CD. 2017. Taxonomic review of Perisesarma (Decapoda: Brachyura: Sesarmidae) and closely related genera based on morphology and molecular phylogenetics: New classification, two new genera and the questionable phylogenetic value of the epibranchial tooth. Zool J Linn Soc 20: 1-32. DOI: 10.1093/zoolinnean/zlx032.

Shih Hsi-Te, Suzuki H. 2016. Species diversity of fiddler crabs, genus Uca Leach, 1814 (Crustacea: Ocypodidae), from Taiwan and adjacent islands, with notes on the Japanese species. Zootaxa 4083 (1): 57-82. DOI: 10.11646/zootaxa.4083.1.3.

Shih H, Ng P, Davie P, Schubart C, Türkay M. 2016b. Systematics of the family Ocypodidae Rafinesque, 1815 (Crustacea: Brachyura), based on phylogenetic relationships, with a reorganization of subfamily rankings and a review of the taxonomic status of Uca Leach, 1814, sensu lato and its subgenera. Raffles Bull Zool 64: 139-175.

Vermeiren P, Abrantes K. Sheaves M. 2015. Generalist and specialist feeding crabs maintain discrete trophic niches within and among estuarine locations. Estuar Coasts 38 (6): 2070-2082. DOI: 10.1007/s12237-015-9959-x. 